\title{
Barriers and Support-System while Considering Hematopoietic Stem Cell Transplant (HSCT): A Qualitative Study of Pre-HSCT Acute Leukemia Patients from a Standalone Transplant Laboratory in India
}

\author{
Hina Solanki $i^{1,2} \quad$ Aseem K Tiwari $^{3} \quad$ Naveen Vashisht ${ }^{1}$ \\ ${ }^{1}$ Chimera Transplant Research Foundation, South Extension Part-II, \\ Masjid Moth, New Delhi, India \\ ${ }^{2}$ Centre for Medical Biotechnology, Amity Institute of \\ Biotechnology, Amity University Uttar Pradesh, Noida, India \\ ${ }^{3}$ Department of Transfusion Medicine, Medanta The Medicity, \\ Gurgaon, Haryana, India \\ ${ }^{4}$ Amity Center for Cancer Epidemiology \& Cancer Research, Amity \\ University Uttar Pradesh, Noida, India
}

Ind J Med Paediatr Oncol 2021;42:153-160.

\author{
Vimarsh Raina $\quad$ Girish Sharma ${ }^{2,4}$
}

\author{
Address for correspondence Girish Sharma, PhD, Amity Center for \\ Cancer Epidemiology \& Cancer Research, Amity University Uttar \\ Pradesh, Sector-125, Noida 201313, India \\ (e-mail: gsharma3@amity.edu, sharmagi03@gmail.com).
}

\begin{abstract}
Keywords

- acute leukemia

- barriers

- hematopoietic stem cell transplant (HSCT)

- matched unrelated donor (MUD)

- support-system
\end{abstract}

Introduction Hematopoietic stem cell transplant (HSCT) is the definite treatment for acute leukemia but considering HSCT is challenging for the patients. There are many studies that have described the patients' experience after HSCT but very few studies have reported their experience before going for HSCT and there is no published report in India on patients' experience before HSCT.

Objective We conducted a qualitative study to understand barriers, and supportsystem while considering HSCT and the chances of getting matched unrelated donor (MUD) for these patients.

Materials and Methods The present study was a qualitative study. Demographic details of 514 patients who consented for the study were noted and the patients and their families were interviewed using a semistructured interview booklet before HSCT. The interview sessions were recorded, transcribed verbatim, and analyzed for emerging themes. The study data were analyzed using QDA Miner Lite 4.0 software (Provalis Research, Montreal, Canada). Descriptive statistics such as frequency and percentage were used. The chances of getting a human leukocyte antigen (HLA)-matched donor were also computed by "HLA-matching software."

Results Acute myeloid leukemia (64.01\%) was commoner than acute lymphoid leukemia (35.99\%) with male: female ratio as 1.98:1. The study showed nine themes as barriers and six themes emerged in regard to the support system for HSCT decision making. The biggest barriers identified among these patients pre-HSCT were related to cost, probability of "success of transplant," and probable "quality of life." The family support was the biggest support system variable followed by "treating doctor."
DoI https://doi.org/ $10.1055 / \mathrm{s}-0041-1730091$ ISSN 0971-5851

\footnotetext{
(c) 2021. Indian Society of Medical and Paediatric Oncology. This is an open access article published by Thieme under the terms of the Creative Commons Attribution-NonDerivative-NonCommercial-License, permitting copying and reproduction so long as the original work is given appropriate credit. Contents may not be used for commercial purposes, or adapted, remixed, transformed or built upon. (https://creativecommons.org/licenses/by-nc-nd/4.0/). Thieme Medical and Scientific Publishers Private Ltd. A-12, Second Floor, Sector -2, NOIDA -201301, India
} 
The chances of getting a MUD for these patients were $13.22 \%$ and $5.44 \%$ in global and Indian data pool, respectively.

Conclusion Deciding upon HSCT can be challenging for patients and understanding of barriers and support-system variables among these patients would provide important insights and help design better counseling techniques for such patients of HSCT and future studies in this context.

\section{Introduction}

Allogeneic hematopoietic stem cell transplantation (HSCT) is an accepted and definitive treatment option for patients with acute leukemia. ${ }^{1}$ The number of patients opting for HSCT as a definitive treatment in India is increasing with increasing awareness of blood disorders and their definitive treatment options. While long-term survival of patients with acute leukemia is dismal without HSCT, the decision-making to opt for HSCT is challenging for both patients and their families. ${ }^{2}$ Mental health, social, and economic issues of these patients affect the transplant outcomes. ${ }^{3}$ An understanding of the barriers faced by these patients and the patients' key influential factors when choosing HSCT is very important for medical staff, which can then be used as a guide during their discussions with the patients before HSCT. India being a highly populous country lacks robust medical infrastructure that needs to understand the dilemma of these patients. Ignorance regarding the HSCT procedure increases the hurdles of patients with acute leukemia who count on time.

The present study was probably the first attempt in India to describe the baseline data focusing mainly on the qualitative aspect of the barriers and support-system variables from the perspective of patients with acute leukemia and their families during the pre-HSCT workup phase.

\section{Materials and Methods}

\section{Study Setting}

This present qualitative study was conducted at a molecular transplant laboratory with a matched unrelated donor (MUD) registry in the national capital region (NCR), north India, where these patients were referred by different treating physicians from different hospitals for pre-HSCT workup tests or

Table 1 Sample questions from interview booklet asked to prospective HSCT patients/family members

- Do you know what HSCT is?

- When and how did you first know about HSCT as a treatment option for you (your family)?

- Do you have a family donor?

- Which are the barriers that you perceive when deciding on prospective HSCT?

- What are your concerns pertaining to HSCT?

- Who helped you to go for possible HSCT?

Abbreviations: HSCT, hematopoietic stem cell transplant. for a voluntary stem cell donor search from January 2015 to December 2019. The study analyzed the data of 514 pre-HSCT candidates who have had an HSCT consultation, and diagnosed as acute lymphoid leukemia (ALL) or acute myeloid leukemia (AML) with disease status as "not responding to chemotherapy" or relapsed acute leukemia. HSCT was recommended as a suitable treatment option for these patients by their physicians. All the participants belonged to the middle socioeconomic status, with the annual family income varying between INR 5 lakh and INR 30 lakh. Of the 602 patients with acute leukemia visiting our laboratory during the study period and seeking allogeneic transplant, 514 patients provided written consent to participate in this study.

\section{Demographic Data}

The demographic data regarding age, gender, year of diagnosis, type of disease, and laboratory reports such as peripheral blood counts and human leukocyte antigen (HLA) typing of all 514 participants were collected.

\section{Interview Process and Data Analysis}

Patients aged more than 18 years were interviewed individually, whereas those aged less than 18 were interviewed in the presence of their immediate family member (usually a parent or an elder sibling) either during their visit to our standalone transplant laboratory or at their residence to understand their biggest barriers and the support system that helped them to opt for the possible HSCT. The interview booklet comprised of open-ended questions. - Table 1 presents the sample questions asked during the interview process. The participants were interviewed by a member of the investigating team not involved in the clinical care of the patients. All interviews were recorded and transcribed verbatim and coded using QDA Miner Lite 4.0 software (Provalis Research, Montreal, Canada). The interview data were analyzed using thematic analysis, which searches for themes that emerge from the primary interview data. The analysis was performed independently by a team comprising the laboratory director, another qualified medical doctor, and a clinical psychologist to understand the emerging themes. The team discussed the responses and agreed unanimously on the theme categorization for the purpose of accuracy.

\section{Statistical Analysis}

The sample size of many of the subgroups was small; therefore, descriptive statistics such as frequency and percentage were used to compare the themes reported by acute leukemia 
patients (family members). The statistical analysis was performed using Microsoft Excel 2010 (Microsoft Corporation, Redmond, Washington, United States).

\section{MUD Search}

A global MUD search was performed for the 514 patients to determine the probability of obtaining an MUD match for these patients in the global and Indian registries. The laboratory contacted a voluntary stem cell donor registry, which was also located in the NCR, India. ${ }^{4}$ The search was performed on the web portal, World Marrow Donor Association, which is a centralized global database of the HLA phenotypes of adult voluntary stem cell donors across the globe. ${ }^{5}$ The search algorithm of the registry utilized only high-resolution HLA typing results at the HLA-A, -B, -C, -DRB1, and -DQB1 loci, with two alleles at each loci. Full 10/10 HLA matching was considered a "match" between the donor and recipient. The matches with the probabilities of becoming a full 10/10 match after the workup stages were excluded from the study. The present study did not include secondary selection criteria such as age, gender, donor availability, and cytomegalovirus status in the search algorithm. Treating physicians had full freedom to add or modify the selection criteria, if they so felt.

\section{Ethics}

The identity of the patients was kept confidential, and no personal identifiers such as name, address, and ethnicity were used. A written consent was obtained from the patients or family members before the interview. Ethical approval was obtained from the Institutional Ethics Committee for Health-Related Research (ECG001, Date: May 9, 2019). The study has been performed in accordance with ethical committee and the ethical standards as laid down in the 1964 Declaration of Helsinki as revised in 2013.

\section{Results}

\section{Demographic Data}

The study data comprised those of $64.01 \%$ patients with AML and $35.99 \%$ patients with ALL. - Table 2 presents the details of the age and disease split. Of the 514 participants, $66.53 \%$ were male and $33.46 \%$ were female, with a male to female ratio of $1.98: 1$. Among the patients with AML, $63.83 \%$ were male and $36.17 \%$ were female, whereas among those with ALL, $71.35 \%$ were male and $28.65 \%$ were female.

\section{Themes as Barriers while considering HSCT in Patients with Acute Leukemia}

Nine themes were identified as barriers. The barriers quoted by the patients and their families are presented in - Table $\mathbf{3}$, whereas the frequency of each barrier theme is presented in - Table 4. The top three themes mentioned as barriers while considering HSCT were "Cost of the transplant," "Not sure of success of transplant," and "Questionable quality of life after HSCT." Most of the patients mentioned that they do not have any health insurance or financial support to cover the transplant expenses. The cost of treatments and medicines posttransplant was also declared to be high by most patients. Some of the patients mentioned that they had already spent a substantial amount of their savings in the ongoing treatment and would not be able to spend "this much" on HSCT treatment and that further expenses would possibly cause a "financial crisis." Few of them also mentioned that she/he was the only earning member of the family. Therefore, treatment cost was found to be a vital barrier. This factor was common in every age group, and $44.94 \%$ patients considered it as the biggest barrier while considering HSCT. Approximately $45 \%$ of both male and female patients provided this response.

The second most common (25.88\%) barrier that the patients mentioned was the "uncertainty about the success of the transplant." This theme was the most common among the age group of 41 to 50 years, wherein $32.39 \%$ patients mentioned this as a barrier. A few of them mentioned that given the high costs of transplant and the lack of absolute certainty of successful treatment, they were worried about the outcome and possibility of failure of this treatment.

The third most common barrier theme was the "questionable quality of life after the transplant," which was reported by $17.90 \%$ of the patients. The obtained proportion of this response in all age groups was almost equal. Several parents of patients aged less than 10 years wanted a normal childhood for their children, which was lacking until then. They questioned the viability of the

Table 2 Age-wise distribution of AML and ALL among prospective HSCT patients

\begin{tabular}{|l|l|l|l|l|l|}
\hline & \multicolumn{2}{|c|}{ AML } & \multicolumn{2}{c|}{ ALL } & Total \\
\hline Age group & No. of patients & $\%$ & No. of patients & $\%$ & \\
\hline $1-10$ & 31 & 9.42 & 29 & 15.68 & $60(11.67 \%)$ \\
\hline $11-20$ & 37 & 11.25 & 49 & 26.49 & $86(16.73 \%)$ \\
\hline $21-30$ & 62 & 18.84 & 43 & 23.24 & $105(20.43 \%)$ \\
\hline $31-40$ & 66 & 20.06 & 37 & 20 & $103(20.04 \%)$ \\
\hline $41-50$ & 51 & 15.50 & 20 & 10.81 & $71(13.81 \%)$ \\
\hline $51-60$ & 66 & 20.06 & 06 & 3.24 & $72(14.08 \%)$ \\
\hline $61-70$ & 12 & 3.65 & 01 & 0.54 & $13(2.53 \%)$ \\
\hline$>70$ & 04 & 1.22 & 0 & 0 & $04(0.78 \%)$ \\
\hline Total & 329 & 100 & 185 & 100 & 514 \\
\hline
\end{tabular}

Abbreviations: ALL, acute lymphoid leukemia; AML, acute myeloid leukemia; HSCT, hematopoietic stem cell transplant. 
Table 3 Themes reported as barriers and supporters with examples of actual answers given by prospective HSCT patients/family members

\begin{tabular}{|c|c|}
\hline \multicolumn{2}{|r|}{ Barriers of acute leukemia patients while considering HSCT } \\
\hline Theme $(n=9)$ Barrier variables & Exemplar quotes \\
\hline Cost of transplant & $\begin{array}{l}\text { "Being from a lower middle-class family, it's very difficult for me to arrange for this huge amount of } \\
\text { money for treatment as I also have to pay heed to all my children and their future. But if the cost of } \\
\text { treatment ensures longevity, I will consider it first." (Patient) }\end{array}$ \\
\hline $\begin{array}{l}\text { Availability of } 10 / 10 \mathrm{HLA}^{*} \\
\text { matched donor }\end{array}$ & $\begin{array}{l}\text { "We don't have a family donor.....we know this is the best and only option available for my brother's } \\
\text { disease but we are worried about getting a matched donor for him" (Sibling) }\end{array}$ \\
\hline $\begin{array}{l}\text { Questionable quality of life after } \\
\text { HSCT }\end{array}$ & $\begin{array}{l}\text { "They say that you lose a part of yourself in the course of this treatment....My son wants to play } \\
\text { cricket like his friends...he wants to go to school every day and enjoy with his friends...I don't know } \\
\text { whether his treatment would give him the life he desires for." (Parent) }\end{array}$ \\
\hline No social acceptance after HSCT & $\begin{array}{l}\text { "I know post-treatment, it will be hard for people to accept me. In my social circle, I hope people still } \\
\text { see me as my old self, someone who just beat a disease and not as an outcaste." (Patient) }\end{array}$ \\
\hline $\begin{array}{l}\text { Apprehension about side effect of } \\
\text { HSCT therapy }\end{array}$ & $\begin{array}{l}\text { "When the doctor told us about the side effects that I will go through, I was taken aback...I can } \\
\text { possibly even die from it...." (Patient) }\end{array}$ \\
\hline Not sure of success of transplant & $\begin{array}{l}\text { "My fear is if this treatment will work on me or not..... My family is arranging money for my trans- } \\
\text { plant....If it doesn't work, then they will be broken to the core." (Patient) }\end{array}$ \\
\hline $\begin{array}{l}\text { Fertility } \\
\text { Loss of job } \\
\text { Duration of stay in hospital }\end{array}$ & $\begin{array}{l}\text { "Being a 24-year married woman with low chances of conceiving after the treatment makes me } \\
\text { scared. If nothing, the social stigma of having cancer and childlessness will surely kill my soul." } \\
\text { (Patient) } \\
\text { "To take a treatment, I have to give up my job for at least a year. With no potential job offers in sight } \\
\text { and degrading health, this might be my only shot at gaining my life back on track."(Patient) } \\
\text { "I have been admitted in the hospital quite often and I despise every moment of living here. The } \\
\text { longer the duration, the more psychologically weak I am becoming....I don't know how long will I } \\
\text { stay in the hospital after the transplant.... I sometimes resort to praying and keeping faith in God as } \\
\text { it is the only thing that is keeping me sane." (Patient) }\end{array}$ \\
\hline \multicolumn{2}{|r|}{ Support-system variables of acute leukemia patients while considering HSCT } \\
\hline $\begin{array}{l}\text { Theme }(n=6) \text { support-system } \\
\text { variable }\end{array}$ & Exemplar quotes \\
\hline A family member & $\begin{array}{l}\text { "The support of my family is the biggest during these testing times. I have two more kids, they are } \\
\text { with their grandparents so that me and my wife can take care of B. in the hospital.....It's just their } \\
\text { support that we decided for transplant" (Parent) }\end{array}$ \\
\hline A friend & $\begin{array}{l}\text { "My parents live in village and it's difficult for them to be with me every time during and after the } \\
\text { transplant....even to understand the whole procedure. I am blessed with a bunch of my college } \\
\text { friends who make me feel sane and above all, treat me as a normal person..." (Patient) }\end{array}$ \\
\hline Coworker & $\begin{array}{l}\text { "Seldom you come across coworkers disguised as friends and family. I am relieved that I have some } \\
\text { of the best in my life.....they are helping me at work and during my treatment..." } \\
\text { (Patient) }\end{array}$ \\
\hline Doctor or medical staff & $\begin{array}{l}\text { "I didn't know anything about transplant. My doctor told that this is the best option available for } \\
\text { me. I have full trust in my doctor as he is the best for this treatment. I am doing this just because he } \\
\text { recommended me" (Patient) }\end{array}$ \\
\hline $\begin{array}{l}\text { This was the only option available } \\
\text { for me }\end{array}$ & $\begin{array}{l}\text { "I have two choices; either fight or give in. I chose the former because I want to live and experience } \\
\text { the world like a normal person. It is the only thing that can cure and save my life." (Patient) }\end{array}$ \\
\hline $\begin{array}{l}\text { I just would like to for HSCT based } \\
\text { on my belief in God }\end{array}$ & $\begin{array}{l}\text { "Whenever I was worried and was struggling with the disease my mother told me to chant holy } \\
\text { mantra's and that really worked for me....i would like to continue doing that and keeping faith in } \\
\text { god I have decided to go for transplant." (Patient) }\end{array}$ \\
\hline
\end{tabular}

Abbreviations: HLA, human leukocyte antigen; HSCT, hematopoietic stem cell transplant.

*signifies the probability of finding a 10/10 HLA-matched MUD search for acute leukemia patients in the global and Indian registries.

treatment and if it could ever give them a normal life afterward? A few patients (10.89\%) perceived "availability of 10/10 HLA matched donor" as the barrier to considering HSCT. The availability of a family or unrelated 10/10 matched donor for the transplant was a major concern for many patients. Some of the patients mentioned that if they get a family donor it would be much easier to decide to opt for HSCT as the cost and the time required were less than a MUD transplant. The other factors "apprehensions about the side effect of the HSCT therapy" (8.17\%) and "no social acceptance after HSCT" (7.39\%) were also mentioned. Patients also expressed their anxiety regarding the serious side effects, including mortality associated with the treatments. The social acceptance factor was observed more in females (9.4\%) than in males (6.43\%). Other themes included concerns regarding fertility, loss of job, and duration of stay in hospital after transplant.

\section{Themes as Support-system Variables of Patients with Acute Leukemia while considering HSCT}

- Table 3 presents the six themes identified as support-system variables and the examples quoted by the patients and 
Barriers and Support-System while considering HSCT Solanki et al. 157

Table 4 Frequency of each theme reported by acute leukemia patients (family members) while considering prospective HSCT

\begin{tabular}{|c|c|c|c|c|c|c|c|c|c|c|c|c|c|}
\hline \multicolumn{14}{|c|}{ Barriers of acute leukemia patients while considering HSCT } \\
\hline & $\begin{array}{l}\text { Theme } \\
(n=9)\end{array}$ & $\begin{array}{l}\text { Cost of } \\
\text { transplant }\end{array}$ & \begin{tabular}{|l} 
Not \\
sure of \\
success of \\
transplant
\end{tabular} & $\begin{array}{r}\text { Ques } \\
\text { quali } \\
\text { afte }\end{array}$ & $\begin{array}{l}\text { stionable } \\
\text { ity of life } \\
\text { er HSCT }\end{array}$ & & $\begin{array}{l}\text { /ailability } \\
\text { f } 10 / 10 \\
\text { HLA }^{*} \\
\text { natched } \\
\text { donor }\end{array}$ & $\begin{array}{r}\text { App } \\
a b \\
\text { effe } \\
t\end{array}$ & $\begin{array}{l}\text { orehension } \\
\text { bout side } \\
\text { ect of HSCT } \\
\text { therapy }\end{array}$ & $\begin{array}{c}\text { No social } \\
\text { accep- } \\
\text { tance after } \\
\text { HSCT }\end{array}$ & Ferti & $\begin{array}{l}\text { yoss } \\
\text { of } \\
\text { job }\end{array}$ & $\begin{array}{l}\text { Duration of stay } \\
\text { in hospital }\end{array}$ \\
\hline & $\begin{array}{l}\text { No. of } \\
\text { candidates }\end{array}$ & $n(\%)$ & $n(\%)$ & $n(\%)$ & & $n(\%$ & $\%)$ & $n(\%$ & & $n(\%)$ & $n(\%)$ & $n(\%)$ & $n(\%)$ \\
\hline & 514 & \begin{tabular}{|l|}
231 \\
$(44.94)$
\end{tabular} & $\begin{array}{l}133 \\
(25.88)\end{array}$ & & $\begin{array}{c}92 \\
17.90)\end{array}$ & & $\begin{array}{c}56 \\
(10.89)\end{array}$ & & $\begin{array}{c}42 \\
(8.17)\end{array}$ & $\begin{array}{c}38 \\
(7.39)\end{array}$ & $\begin{array}{r}7 \\
(1.3\end{array}$ & $\begin{array}{l}3 \\
(0.58)\end{array}$ & $\begin{array}{l}3 \\
(0.58)\end{array}$ \\
\hline \multicolumn{14}{|l|}{ Age } \\
\hline $1-10$ & 60 & \begin{tabular}{|l|}
24 \\
$(40.00)$
\end{tabular} & \begin{tabular}{|l|}
16 \\
$(26.67)$
\end{tabular} & & $\begin{array}{c}10 \\
16.67)\end{array}$ & & $\begin{array}{c}4 \\
(6.67)\end{array}$ & & $\begin{array}{c}4 \\
(6.67)\end{array}$ & $\begin{array}{c}2 \\
(3.33)\end{array}$ & $\begin{array}{r}0 \\
(0.0\end{array}$ & \begin{tabular}{|l|}
0 \\
$(0.00)$
\end{tabular} & \begin{tabular}{|l}
0 \\
$(0.00)$
\end{tabular} \\
\hline $11-20$ & 86 & \begin{tabular}{|l|}
36 \\
$(41.86)$
\end{tabular} & \begin{tabular}{|l|}
17 \\
$(19.77)$
\end{tabular} & & $\begin{array}{c}16 \\
18.60)\end{array}$ & & $\begin{array}{c}7 \\
(8.14)\end{array}$ & & $\begin{array}{c}8 \\
(9.30)\end{array}$ & $\begin{array}{c}4 \\
(4.65)\end{array}$ & $\begin{array}{r}1 \\
(1.1\end{array}$ & \begin{tabular}{|l|}
0 \\
$(0.00)$
\end{tabular} & $\begin{array}{l}1 \\
(1.16)\end{array}$ \\
\hline $21-30$ & 105 & \begin{tabular}{|l}
59 \\
$(56.19)$
\end{tabular} & \begin{tabular}{|l|}
27 \\
$(25.71)$
\end{tabular} & & $\begin{array}{c}19 \\
18.10)\end{array}$ & & $\begin{array}{c}12 \\
(11.43)\end{array}$ & & $\begin{array}{c}8 \\
(7.62)\end{array}$ & $\begin{array}{c}9 \\
(8.57)\end{array}$ & $\begin{array}{r}4 \\
(3.8\end{array}$ & \begin{tabular}{|l|}
0 \\
$(0.00)$
\end{tabular} & \begin{tabular}{|l|}
0 \\
$(0.00)$
\end{tabular} \\
\hline $31-40$ & 103 & \begin{tabular}{|l}
54 \\
$(52.43)$
\end{tabular} & \begin{tabular}{|l}
28 \\
$(27.18)$
\end{tabular} & & $\begin{array}{c}18 \\
17.48)\end{array}$ & & $\begin{array}{c}13 \\
(12.62)\end{array}$ & & $\begin{array}{c}11 \\
(10.68)\end{array}$ & $\begin{array}{c}10 \\
(9.71)\end{array}$ & $\begin{array}{r}2 \\
(4.8\end{array}$ & $\begin{array}{l}1 \\
(0.97)\end{array}$ & $\begin{array}{l}0 \\
(0.00)\end{array}$ \\
\hline $41-50$ & 71 & \begin{tabular}{|l|}
29 \\
$(40.85)$
\end{tabular} & \begin{tabular}{|l|}
23 \\
$(32.39)$
\end{tabular} & & $\begin{array}{c}12 \\
16.90)\end{array}$ & & $\begin{array}{c}8 \\
(11.27)\end{array}$ & & $\begin{array}{c}4 \\
(5.63)\end{array}$ & $\begin{array}{c}6 \\
(8.45)\end{array}$ & $\begin{array}{r}0 \\
(0.0\end{array}$ & $\begin{array}{l}2 \\
(2.82)\end{array}$ & $\begin{array}{l}1 \\
(1.41)\end{array}$ \\
\hline $51-60$ & 72 & \begin{tabular}{|l}
21 \\
$(29.17)$
\end{tabular} & \begin{tabular}{|l|}
20 \\
$(27.78)$
\end{tabular} & & $\begin{array}{c}14 \\
19.44)\end{array}$ & & $\begin{array}{c}9 \\
(12.50)\end{array}$ & & $\begin{array}{c}6 \\
(8.33)\end{array}$ & $\begin{array}{c}4 \\
(5.56)\end{array}$ & $\begin{array}{r}0 \\
(0.0\end{array}$ & \begin{tabular}{|l|}
0 \\
$(0.00)$
\end{tabular} & $\begin{array}{l}1 \\
(1.39)\end{array}$ \\
\hline $61-70$ & 13 & \begin{tabular}{|l|}
6 \\
$(46.15)$
\end{tabular} & \begin{tabular}{|l|}
2 \\
$(15.38)$
\end{tabular} & & $\begin{array}{c}2 \\
15.38)\end{array}$ & & $\begin{array}{c}3 \\
(23.08)\end{array}$ & & $\begin{array}{c}1 \\
(7.69)\end{array}$ & $\begin{array}{c}2 \\
(15.38)\end{array}$ & $\begin{array}{r}0 \\
(0.0\end{array}$ & \begin{tabular}{|l|}
0 \\
$(0.00)$
\end{tabular} & \begin{tabular}{|l}
0 \\
$(0.00)$
\end{tabular} \\
\hline$>70$ & 04 & \begin{tabular}{|l}
2 \\
$(50.00)$
\end{tabular} & $\begin{array}{l}0 \\
(0.00)\end{array}$ & & $\begin{array}{c}1 \\
25.00)\end{array}$ & & $\begin{array}{c}0 \\
(0.00)\end{array}$ & & $\begin{array}{c}0 \\
(0.00)\end{array}$ & $\begin{array}{c}1 \\
(25.00\end{array}$ & $\begin{array}{r}0 \\
(0.0\end{array}$ & \begin{tabular}{|l|}
0 \\
$(0.00)$
\end{tabular} & \begin{tabular}{|l}
0 \\
$(0.00)$
\end{tabular} \\
\hline \multicolumn{14}{|l|}{ Sex } \\
\hline Male & 342 & \begin{tabular}{|l}
156 \\
$(45.91)$
\end{tabular} & \begin{tabular}{|l}
92 \\
$(26.90)$
\end{tabular} & & $\begin{array}{c}63 \\
18.42)\end{array}$ & & $\begin{array}{c}39 \\
(11.40)\end{array}$ & & $\begin{array}{c}29 \\
(8.48)\end{array}$ & $\begin{array}{c}22 \\
(6.43)\end{array}$ & $\begin{array}{r}2 \\
(0.5\end{array}$ & $\begin{array}{l}3 \\
(0.88)\end{array}$ & $\begin{array}{l}2 \\
(0.58)\end{array}$ \\
\hline Female & 172 & $\begin{array}{l}75 \\
(43.60)\end{array}$ & $\begin{array}{l}41 \\
(23.84)\end{array}$ & & $\begin{array}{c}29 \\
16.86)\end{array}$ & & $\begin{array}{c}17 \\
(9.880\end{array}$ & & $\begin{array}{c}13 \\
(7.56)\end{array}$ & $\begin{array}{c}16 \\
(9.30)\end{array}$ & $\begin{array}{r}5 \\
(2.9\end{array}$ & \begin{tabular}{|l|}
0 \\
$(0.00)$
\end{tabular} & $\begin{array}{l}1 \\
(0.58)\end{array}$ \\
\hline \multicolumn{14}{|c|}{ Support-system variables of acute leukemia patients while considering HSCT } \\
\hline & $\begin{array}{l}\text { Theme } \\
(n=6)\end{array}$ & $\begin{array}{l}\text { A family } \\
\text { member }\end{array}$ & \multicolumn{2}{|c|}{$\begin{array}{l}\text { Doctor or medi- } \\
\text { cal staff }\end{array}$} & \multicolumn{2}{|c|}{$\begin{array}{c}\text { This was the } \\
\text { only option } \\
\text { available for } \\
\text { me }\end{array}$} & \multicolumn{2}{|c|}{$\begin{array}{c}\text { I just would } \\
\text { like to for } \\
\text { HSCT based } \\
\text { on my belief } \\
\text { in God }\end{array}$} & A friend & \multicolumn{2}{|c|}{ Coworker } & & \\
\hline & $\begin{array}{l}\text { No. of } \\
\text { candidates }\end{array}$ & $\begin{array}{l}n \\
(\%)\end{array}$ & \multicolumn{2}{|l|}{$\begin{array}{c}n \\
(\%)\end{array}$} & \multicolumn{2}{|l|}{$\begin{array}{c}n \\
(\%)\end{array}$} & \multicolumn{2}{|c|}{\begin{tabular}{|c|}
$n$ \\
$(\%)$ \\
\end{tabular}} & $\begin{array}{c}n \\
(\%)\end{array}$ & \multicolumn{2}{|c|}{$\begin{array}{c}n \\
(\%)\end{array}$} & & \\
\hline & 514 & \begin{tabular}{|l|}
232 \\
$(45.14)$ \\
\end{tabular} & \multicolumn{2}{|c|}{$\begin{array}{c}159 \\
(30.93)\end{array}$} & \multicolumn{2}{|c|}{$\begin{array}{c}112 \\
(21.79)\end{array}$} & \multicolumn{2}{|c|}{$\begin{array}{c}48 \\
(9.34)\end{array}$} & $\begin{array}{c}8 \\
(1.56)\end{array}$ & \multicolumn{2}{|c|}{$\begin{array}{c}2 \\
(0.39)\end{array}$} & & \\
\hline \multicolumn{14}{|l|}{ Age } \\
\hline $1-10$ & 60 & $\begin{array}{l}28 \\
(46.67)\end{array}$ & \multicolumn{2}{|c|}{$\begin{array}{c}18 \\
(30.00)\end{array}$} & \multicolumn{2}{|c|}{$\begin{array}{c}12 \\
(20.00)\end{array}$} & \multicolumn{2}{|c|}{$\begin{array}{c}4 \\
(6.67)\end{array}$} & $\begin{array}{c}1 \\
(1.67)\end{array}$ & \multicolumn{2}{|c|}{$\begin{array}{c}0 \\
(0.00)\end{array}$} & & \\
\hline $11-20$ & 86 & \begin{tabular}{|l}
39 \\
$(45.35)$
\end{tabular} & \multicolumn{2}{|c|}{$\begin{array}{c}34 \\
(39.53)\end{array}$} & \multicolumn{2}{|c|}{$\begin{array}{c}15 \\
(17.44)\end{array}$} & \multicolumn{2}{|c|}{$\begin{array}{c}2 \\
(2.33)\end{array}$} & $\begin{array}{c}0 \\
(0.00)\end{array}$ & $\begin{array}{c}0 \\
(0.00 \\
\end{array}$ & & & \\
\hline $21-30$ & 105 & \begin{tabular}{|l|}
49 \\
$(46.67)$
\end{tabular} & $\begin{array}{c}37 \\
(35.24)\end{array}$ & & $\begin{array}{c}27 \\
(25.71\end{array}$ & & $\begin{array}{c}8 \\
(7.62\end{array}$ & & $\begin{array}{c}1 \\
(0.95)\end{array}$ & $\begin{array}{c}1 \\
(0.95\end{array}$ & & & \\
\hline $31-40$ & 103 & \begin{tabular}{|l}
41 \\
$(39.81)$
\end{tabular} & $\begin{array}{c}32 \\
(31.07)\end{array}$ & & $\begin{array}{c}31 \\
(30.10\end{array}$ & & $\begin{array}{c}13 \\
(12.62\end{array}$ & & $\begin{array}{c}2 \\
(1.94)\end{array}$ & $\begin{array}{r}1 \\
(0.97 \\
\end{array}$ & & & \\
\hline $41-50$ & 71 & \begin{tabular}{|l|}
31 \\
$(43.66)$
\end{tabular} & $\begin{array}{c}15 \\
(21.13)\end{array}$ & & $\begin{array}{c}16 \\
(22.54\end{array}$ & & $\begin{array}{c}7 \\
(9.86\end{array}$ & & $\begin{array}{c}3 \\
(4.23)\end{array}$ & $\begin{array}{c}0 \\
(0.00\end{array}$ & & & \\
\hline $51-60$ & 72 & \begin{tabular}{|l|}
36 \\
$(50.00)$
\end{tabular} & $\begin{array}{c}18 \\
(25.00)\end{array}$ & & $\begin{array}{c}9 \\
(12.50\end{array}$ & & $\begin{array}{c}10 \\
(13.89\end{array}$ & & $\begin{array}{c}1 \\
(1.39)\end{array}$ & $\begin{array}{c}0 \\
(0.00\end{array}$ & & & \\
\hline
\end{tabular}




\begin{tabular}{|c|c|c|c|c|c|c|c|c|c|c|}
\hline \multicolumn{11}{|c|}{ Barriers of acute leukemia patients while considering HSCT } \\
\hline & $\begin{array}{l}\text { Theme } \\
(n=9)\end{array}$ & $\begin{array}{l}\text { Cost of } \\
\text { transplant }\end{array}$ & \begin{tabular}{|l|} 
Not \\
sure of \\
success of \\
transplant
\end{tabular} & $\begin{array}{c}\text { Questionable } \\
\text { quality of life } \\
\text { after HSCT }\end{array}$ & $\begin{array}{c}\text { Availability } \\
\text { of } 10 / 10 \\
\text { HLA* } \\
\text { matched } \\
\text { donor }\end{array}$ & \begin{tabular}{|c|} 
Apprehension \\
about side \\
effect of HSCT \\
therapy
\end{tabular} & \begin{tabular}{|c|} 
No social \\
accep- \\
tance after \\
HSCT
\end{tabular} & Fertility & $\begin{array}{l}\text { Loss } \\
\text { of } \\
\text { job }\end{array}$ & $\begin{array}{l}\text { Duration of stay } \\
\text { in hospital }\end{array}$ \\
\hline & \begin{tabular}{|l|} 
No. of \\
candidates
\end{tabular} & $n(\%)$ & $n(\%)$ & $n(\%)$ & $n(\%)$ & $n(\%)$ & $n(\%)$ & $n(\%)$ & $n(\%)$ & $n(\%)$ \\
\hline $61-70$ & 13 & $\begin{array}{l}6 \\
(46.15)\end{array}$ & $\begin{array}{c}4 \\
(30.77)\end{array}$ & $\begin{array}{c}2 \\
(15.38)\end{array}$ & $\begin{array}{c}3 \\
(23.08)\end{array}$ & $\begin{array}{c}0 \\
(0.00)\end{array}$ & $\begin{array}{c}0 \\
(0.00)\end{array}$ & & & \\
\hline$>70$ & 04 & \begin{tabular}{|l|}
2 \\
$(50.00)$
\end{tabular} & $\begin{array}{c}1 \\
(25.00)\end{array}$ & $\begin{array}{c}0 \\
(0.00)\end{array}$ & $\begin{array}{c}1 \\
(25.00)\end{array}$ & $\begin{array}{c}0 \\
(0.00)\end{array}$ & $\begin{array}{c}0 \\
(0.00)\end{array}$ & & & \\
\hline \multicolumn{11}{|l|}{ Sex } \\
\hline Male & 342 & \begin{tabular}{|l}
161 \\
$(47.08)$
\end{tabular} & $\begin{array}{c}108 \\
(31.58)\end{array}$ & $\begin{array}{c}82 \\
(23.98)\end{array}$ & $\begin{array}{c}25 \\
(7.31)\end{array}$ & $\begin{array}{c}6 \\
(1.75)\end{array}$ & $\begin{array}{c}2 \\
(0.58)\end{array}$ & & & \\
\hline Female & 172 & \begin{tabular}{|l}
71 \\
$(41.28)$
\end{tabular} & $\begin{array}{c}51 \\
(29.65)\end{array}$ & $\begin{array}{c}30 \\
(17.44)\end{array}$ & $\begin{array}{c}23 \\
(13.37)\end{array}$ & $\begin{array}{c}2 \\
(1.16)\end{array}$ & $\begin{array}{c}0 \\
(0.00)\end{array}$ & & & \\
\hline
\end{tabular}

Abbreviations: HLA, human leukocyte antigen; HSCT, hematopoietic stem cell transplant.

Responses are greater than the number of candidates as some of the candidates expressed more than one barrier or support-system variable. *signifies the probability of finding a 10/10 HLA-matched MUD search for acute leukemia patients in the global and Indian registries.

their families, and Table 4 presents the frequency of each support-system variable. A total of $45.14 \%$ patients believed that the support of their family members or spouse was the biggest support-system variable for them while considering HSCT. They mentioned that during the time of stress and undergoing treatment, they always found their family standing up for them and providing them the much-needed positive vibes to ward off the blues caused by this disease. "Family support" was considered the biggest support-system theme by all age groups. Of the total patients, $47.08 \%$ male patients and $41.28 \%$ female patients considered family as the biggest support-system theme.

In India, several patients are ignorant of the HSCT procedure. Thus, the doctor or medical staff helps them understand the procedure. Some of the patients mentioned that before meeting their doctor, they had no or limited knowledge about HSCT as a treatment option. Therefore, insights from the doctors helped them in taking the right decision. Accordingly, 30.93\% of patients opted for this option as per the recommendation of their treating doctor or medical staff. This theme was found to be the most common in the age group 11 to 20 years, and $39.53 \%$ of the total patients in this age group believed that their doctor is the biggest factor while considering HSCT. The proportion of male and female was $31.58 \%$ versus $29.65 \%$, respectively.

The patients with acute leukemia considered "time" as an integral factor as the disease progresses rapidly. A total of $21.79 \%$ of patients mentioned that the disease progression and other failed treatment options left them with "only this alternative." This response was most common in the age group of 31 to 40 years, with $31.10 \%$ of patients. The percentage of male patients (23.98\%) considering it as a factor was higher than the percentage of female patients (17.44\%) considering the same. The "Belief in God" theme was mentioned by a considerable percentage $(9.34 \%)$ of patients as their support system in decision-making for HSCT. These patients mentioned that they had faith in God and the belief that everything was going to be fine. This aspect was coupled with other factors. Many patients stated that they had the support of their family along with belief in the Almighty and the fact that this was the only option available to them and thus, in the name of God, they had opted for HSCT. This theme was more common in older patients and less common in the age group of 11 to 20 years. The percentage of female patients who opted for "belief in God" as their biggest support was higher than that of male patients opting for the same. Only $1.56 \%$ mentioned their friends and $0.39 \%$ mentioned their coworker as a help while considering HSCT. No female has mentioned that a coworker had helped them to take this decision.

\section{MUD Search for Patients with Acute Leukemia}

A 10/10 HLA-matched MUD search including only high-resolution HLA typing results and excluding the matches exhibiting the probabilities of the match after the first- or second-stage workup was conducted for the 514 ( male $=342$, female $=172$ ) patients to analyze the probabilities of obtaining a MUD in the global and Indian registries. We were able to obtain a MUD for 96 (18.67\%) patients. Of these patients, only 28 (5.44\%) patients obtained a MUD from the Indian registry data pool, whereas 68 (13.22\%) patients obtained a MUD from the global registry.

\section{Discussion}

Taking decision to undergo HSCT is difficult and is associated with both physical and psychological impacts on patients. ${ }^{6}$ None of the Indian studies have evaluated the hurdles that patients with acute leukemia face while taking a decision to undergo transplant. India, being a developing 
country, lacks a robust healthcare system as compared with developed countries. Therefore, the present study evaluated the barriers and support-system variables of patients with leukemia with respect to their decision of choosing HSCT.

The cost of transplant was observed to be the biggest barrier among patients in the present study. This finding is concurrent with that of other studies, which suggested that many patients with leukemia do not undergo HSCT because they cannot afford the treatment cost. ${ }^{2}$ In most of the Western countries, transplant treatment is paid either by the insurance company or by the government. It is also studied that the health insurance impacts the outcome of transplant for leukemia patients. ${ }^{7}$ The success of the transplant and quality of life after the HSCT therapy were also found to be the top concerns in the present study; these concerns have been shared by patients with leukemia globally. ${ }^{8,9}$ The need for a matched donor was also a concern among the patients after they understood the transplantation procedure. Concern regarding social acceptance was observed in a small percentage of patients, particularly in female patients. One of the other barriers mentioned by these patients was the effect of transplant on their fertility. In a study, sterility was unacceptable in the majority of male patients after transplant. ${ }^{10}$ The mental status of these patients affects the outcome of the transplant. ${ }^{11}$

The present study exhibited that the family support system prior to and during the ongoing treatment was a major support among these patients. This observation was mirrored in another study, too. ${ }^{12}$ Many patients felt that after meeting their doctors and getting to know about the process and therapy increased their confidence in opting for HSCT. This finding is concurrent with that of another study, where the information and recommendations provided by child's physician were found to be the major factor during decision-making on HSCT treatment. ${ }^{9}$ HSCT as an optimal option available was also one of the themes revealed in the present study. A study conducted in pediatric malignant and nonmalignant patients requiring HSCT reported that a high percentage of patients with malignancy believed that the HSCT was the best available option for them and they fear death in the absence of HSCT. The patients with malignancy were more likely to accept HSCT therapy on the recommendation of their physicians compared with the patients with nonmalignant conditions. ${ }^{13}$ The study further revealed that these patients had utmost faith in God that helped them stay positive. These results are concordant with other studies, which have reported that numerous patients receiving transplant find prayers and spiritual beliefs as a motivational force at each step and that they worship the Almighty before taking any medical decision. ${ }^{14,15}$ The support of coworkers and friends while considering HSCT also emerged as a theme, and the finding is concurrent with that of a study on patients with cancer indicating that $42 \%$ of the male patients considered the information received from their friends and coworkers helped them in medical decision-making. ${ }^{16}$ The present study indicated that every family may have different and more than one themes on barriers and support-system variables. Thus, every family should be counseled by medical teams individually without making any prior assumptions.
These guides regarding barriers and support-system variables can help clinical teams in guiding and conducting crucial discussions with these patients and their families.

A preliminary search for the 514 patients in the global and Indian data pool indicated that only $18.67 \%$ of patients could obtain a 10/10 match. When the search was confined to only the Indian registries, the chances were even lower (5.44\%) because of a very small database. This finding was in agreement with other studies. A study published in 2014 also reported that the chances of an Indian to obtain an MUD are $16 \%$ in the global data pool and $0.008 \%$ in the Indian registries. ${ }^{17}$ Another study in 2018 (as the donor data pool had increased) observed that chances of obtaining a 10/10 MUD in the Indian registry for patients with hematological disorder were $5.83 \%{ }^{18}$ The chances of obtaining a $8 / 8$ match for Whites ( 75\%) were much higher than non-Whites ( 16\%) due to the greater representation of Caucasians in the global database..$^{19}$ The poor representation of Indians (or Asians) in the data pool reduces the probabilities of finding a matched donor for an Indian patient. India, given its greater genetic and ethnic diversity, needs to build a large Indian database to provide benefit to a large number of patients with the disease.

\section{Conclusion}

In conclusion, we found cost and the probability of success of HSCT therapy are the biggest barriers faced by the patients with acute leukemia. These patients find the much-needed solace and support from their families that motivate them. Other similar studies can provide insights into the concerns of patients and can be used to counsel patients and their families to improve the HSCT outcome.

\section{Contributors' Details}

Hina Solanki contributed to data collection, analysis, and wrote the manuscript. Aseem Kumar Tiwari made the critical analysis and edited the manuscript. Naveen Vashisht verified and analyzed the data collection. Vimarsh Raina and Girish Sharma conceived of the presented idea and supervised the findings of this original article. All authors have seen the manuscript and agree to the content and data.

\section{Source of Funding}

No funding has been received for the present study.

\section{Conflict of Interest}

The authors declare no conflict of interest.

\section{References}

1 Singh AK, McGuirk JP. Allogeneic stem cell transplantation: a historical and scientific overview. Cancer Res 2016;76(22):6445-6451

2 Sharma SK, Choudhary D, Gupta N, et al. Cost of hematopoietic stem cell transplantation in India. Mediterr J Hematol Infect Dis 2014;6(1):e2014046

3 Michael A, Andrykowski, Richard P. Psychosocial issues in hematopoietic cell transplantation. In: Thomas ED, Forman SJ, Appelbaum FR, Blume KG, eds. Thomas, hematopoietic cell transplantation. 3rd ed. Blackwell; 2004 497-506 
4 GENEBANDHU. Available at: www.genebandhu.in. Accessed April 13, 2021

5 WMDA. Available at: https://www.wmda.info. Accessed April 13, 2021

6 Akaho R, Sasaki T, Mori S, et al. Psychological factors and survival after bone marrow transplantation in patients with leukemia. Psychiatry Clin Neurosci 2003;57(1):91-96

7 Selby GB, Ali LI, Carter TH, Veseley S, Roy V. The influence of health insurance on outcomes of related-donor hematopoietic stem cell transplantation for AML and CML. Biol Blood Marrow Transplant 2001;7(10):576

8 Farroni JS, Thompson PA, Arif D, Corted JE, Gallagher CM. Ethical issues in patients with leukemia: practice points and educational topics for the clinical oncologist and trainees. J Clin Res Bioeth 2017;(5):314

9 Khemani K, Ross D, Sinha C, Haight A, Bakshi N, Krishnamurti L. Experiences and decision making in hematopoietic stem cell transplant in sickle cell disease: patients' and caregivers' perspectives. Biol Blood Marrow Transplant 2018;24(5):1041-1048

10 Chakrabarti S, Bareford D. A survey on patient perception of reduced-intensity transplantation in adults with sickle cell disease. Bone Marrow Transplant 2007;39(8):447-451

11 Cooke L, Gemmill R, Kravits K, Grant M. Psychological issues of stem cell transplant. Semin Oncol Nurs 2009;25(2):139-150

12 Siston AK, List MA, Daugherty CK, et al. Psychosocial adjustment of patients and caregivers prior to allogeneic bone marrow transplantation. Bone Marrow Transplant 2001;27(11):1181-1188

13 Pelletier W, Hinds PS, Alderfer MA, Fairclough DL, Stegenga K, Pentz RD. Themes reported by families as important when proceeding with pediatric hematopoietic stem cell transplantation. Pediatr Blood Cancer 2014;61(9):1625-1631

14 Johnson KS, Elbert-Avila KI, Tulsky JA. The influence of spiritual beliefs and practices on the treatment preferences of African Americans: a review of the literature. J Am Geriatr Soc 2005;53(4):711-719

15 Ragsdale JR, Hegner MA, Mueller M, Davies S. Identifying religious and/or spiritual perspectives of adolescents and young adults receiving blood and marrow transplants: a prospective qualitative study. Biol Blood Marrow Transplant 2014;20(8):1242-1247

16 Berry DL, Blonquist TM, Pozzar R, Nayak MM. Understanding health decision making: an exploration of homophily. Soc Sci Med 2018;214:118-124

17 Tiwari AK, Bhati-Kushwaha H, Kukreja P, et al. Probability of finding marrow unrelated donor (MUD) for an Indian patient in a multi-national human leukocyte antigen (HLA) registry. Indian J Hematol Blood Transfus 2015;31(2):186-195

18 Tiwari AK, Mishra VC, Tiwari A, et al. Matched unrelated donor hematopoietic progenitor cell transplantation: a report based on a single registry in India. Leuk Res Rep 2019;11:17-20

19 Gragert L, Eapen M, Williams E, et al. HLA match likelihoods for hematopoietic stem-cell grafts in the U.S. registry. N Engl J Med 2014;371(4):339-348 